\title{
Pancasila: The Educational Philosophy Alternative from Indonesia for the World
}

\author{
Lalu Sumardi \\ Faculty of Teacher Training and Education, University of Mataram Mataram 83116, Indonesia
}

\begin{abstract}
Indonesia has been independent for more than a half of a century. However, the educational philosophy and practices still adopt the Western philosophy and practice which do not suit the characteristics of Indonesian students. As a matter of fact, Indonesia has local wisdom values which have been legally established as the foundation of philosophy and educational praxis. This paper discusses local wisdom-based educational philosophy which become the foundation of Indonesian education adopted from the values of the Indonesian local wisdom. The writing method used is Heidegger's Existential hermeneutic Ontology. Based on this method, there is an existential meaning that the philosophical basis of Indonesian education consists of the ideological foundation, instrumental foundation (The 1945 Constitution), and a practical foundation (Laws, Government Regulations, Ministerial Regulations, and Multiculturalism). The ideological, instrumental and practical foundations have two basic concepts, namely; religiosity and humanity. Based on the sources of philosophical, instrumental, and practical values, it is concluded that Indonesia's educational philosophy is the Religious Humanist Multiculturalism. Religious Humanist Multiculturalism is a multi-religious universal values that live in Indonesia and human values that are in line with Indonesia's multicultural national identity.
\end{abstract}

Keywords: Pancasila, Educational philosophy, Religious Humanist Multiculturalism

DOI: $10.7176 / \mathrm{JEP} / 11-12-11$

Publication date: April $30^{\text {th }} 2020$

\section{Introduction}

Indonesia is a big, rich, unique, and strange country. This is reflected in its rich natural resources, socio-culture, and the number of population. Judging from natural resources, Indonesia is the second largest country in the world after Brazil with the richest natural resources (Wikipedia, 2018). In terms of population, Indonesia has a population of 265 million in 2018, and 179.13 million people (67.6\%) are in the productive age category (14-64 years) (Indonesian National Planning Agency 2018). Seen from the socio-culture, Indonesia is inhabited by around 1,128 tribes with 748 languages and their respective cultural characteristics (Central Bureau of Statistics of Indonesia 2018). The data shows that Indonesia has abundant resources. However, it is strange that after being independent for more than 72 years, the people of Indonesia still cannot live in prosperity and Indonesia is still categorized as developing countries. In the education sector, Indonesia still lags behind other countries in the world, including neighboring countries such as Singapore, Malaysia, Brunei Darussalam, Thailand and the Philippines. This can be seen from the Human Development Index (HDI) released by UNDP in 2017, which placed Indonesia in the rank of 124 out of $180 \mathrm{UN}$ member states. This position is far below other ASEAN countries. As a comparison, Singapore ranked $9^{\text {th }}$, Brunei Darussalam ranked $30^{\text {th }}$, Malaysia ranked $62^{\text {nd }}$, Thailand ranked $92^{\text {th }}$, and the Philippines ranked $97^{\text {th }}$ (Masyhud 2018). The results of assessments conducted by PISA and TIMSS also showed that the Mathematic and Scientific skills of Indonesian junior and senior high school students was still below Singapore, Thailand and Malaysia. Even $95 \%$ of Indonesian students have only reached the medium level (Ministry of Education and Culture of Indonesia 2014).

The low quality of Indonesian education and human resources is certainly an obstacle in improving the quality of life and accelerating development. However education has a central role in transmitting knowledge (Gobet 2017; Sumardi, Rispawati, \& Ismail, 2017), developing moral, and skills of the nation's generation (Heafford 1967; Wahyudiati, Rohaeti, Irwanto, Wiyarsi, \& Sumardi, 2020; Sumardi, 2014). All countries in the world lay this task on education. Therefore, if a country can give a quality education, then the human resources will be of high quality. Conversely, if a country cannot provide quality education, then human resources will not be of good quality.

Due to the important role of education in building and developing human resources, countries in the world and international institutions pay great attention to education by providing large budget allocations, providing adequate infrastructure and facilities, and continuously improving human resources and curricula. The report of The International Commission of Financing Global Education Opportunity (2016) stated that from 2012-2014, the disbursement of multilateral funds for education reached $34 \%$ of the total ODA. In the context of Indonesia, since 1999 the budget allocated for education has reached 20\% of the State Budget and the Regional Budget (the 1945 Constitution Article 31 paragraph 4). Large financial support, improvement of facilities and infrastructure, and renewal of human resources, and curriculum revision that have been carried out so far do not bring a significant impact on improving the quality of Indonesian education. This is due to the fact that the improvement of education is carried out only on the instrumental aspects, such as; curriculum, facilities, and human resources that are not 
combined with improvements in the philosophical level of education. As a matter of fact, the philosophy of education is very influential on educational praxis (Biesta \& Peters 2015) and environment (Affifi et al. 2017).

Indonesia is borrowing its philosophy of education from the West, which is called the "incorporate eclecticism" (Siswoyo 2013), through selecting and quoting the opinions of leaders and proponents of prominent Western philosophy of education. Indonesian education is still western-oriented, by adopting the philosophy and education system, so that the Indonesian education is characterized by Liberal ideology (Suharto 2010). Fortunately, there has been no heated debate nor massive rejection of Western philosophy in Indonesia. The government and Indonesian educational experts see this as something normal to strengthen national education. It is different from what happened in African countries and China, where the African philosophers according to Enslin and Horsthemke (2016) oppose western individualism and support the African philosophy of communitarianism and Chinese philosophers according to Zhao (2013) also oppose individualism and adopt China's zhongti xiong traditional values. Indonesia does not have to oppose the philosophy of Western individualism, but it must be realized that culturally, ideologically, and juridically, the Indonesian people have values and culture that must be used as the foundation of educational philosophy and practice. Besides that, what is good in the West is not necessarily good and suitable for Indonesian people, because the Indonesian people have characteristics that are different from other nations. Therefore, Indonesia's philosophy of education should be built on the values, character, and culture of the Indonesian people themselves.

Serious efforts have not been made to understand and practice the philosophy of education that is based on Indonesian values and culture. There have been very little reflections and studies on the philosophy of Indonesian education. So far, the existing studies of Indonesian education philosophy are limited to reviewing the perspectives of Indonesian leaders on education (Siswoyo 2013; Suparlan 2015) and the philosophy of Indonesian education seen from educational practices (Suharto 2010; Wangid 2009). There has been no study of how the philosophy of Indonesian education comes from the Indonesian local values and culture. The lack of study and reflection on Indonesia's educational philosophy shows the marginalization of the study of philosophy of education (Besta \& Peters 2015; Biesta 2015), despite the fact that reflection and studies of the philosophy of education are very important (Biesta \& Peters 2015).

Based on the arguments above, this paper will discuss the sources of Indonesian educational philosophy, the philosophy of Indonesian education, and the concept of educational practice according to the philosophy of Indonesian education.

\section{Methods}

This paper is a hermeneutic study of the philosophical text of the Indonesian state, Pancasila, and the Indonesian state constitution, the 1945 Constitution. The hermeneutic method is appropriate to use because according to Betti, hermeneutics is a tool towards understanding (Bleicher 2013). The hermeneutic method being discussed is Heidegger's hermeneutic method. Heidegger's Hermeneutics is a hermeneutic method that aims to reveal the latent, which means an interpretation to discover the nature of "being" (Mulyono 2013). The essence of "being" is hidden in phenomena or objects. In this study, the essence of "being" is hidden in the text to be interpreted.

In carrying out the interpretation, according to Heidegger, there are several steps to take. First, building interpreters' understanding of phenomena or objects that will be interpreted. According to Heidegger, the starting point of the process of interpretation of a phenomenon or object is the interpreter's understanding. This means that the interpretation will produce the correct interpretation if the interpreter has a good understanding of the phenomenon or object being interpreted. To understand phenomena or objects well, Heidegger asserts that interpreters must have three structures called fore-structure, namely; fore-having (prior knowledge), fore-sight (envisioned future), and fore-conception (previously understood objects). The second aspect is casting (movement of the subject towards the object) and capturing (movement of the object towards the subject). This is where circular hermeneutic processes occur, namely the process of exploring and understanding objects (text) by interpreters and bringing the reality of "being" in the object into the interpreter's understanding. The third is acquisition of meaning. Heidegger said the meaning was hidden in the text and it always developed. The meaning includes the framework of formal existentialism or what is written in the text and what the interpreter articulates through his/her interpretive understanding (Mulyono 2013; Bleicher 2013).

\section{Data}

In Article 2 of Law Number 20 of 2003 concerning the Indonesian National Education System, it is stated that the foundation of Indonesian national education is Pancasila and the 1945 Constitution of the Republic of Indonesia. The statement is formulated as "The National Education is based on Pancasila and the 1945 Constitution of the Republic of Indonesia". Pancasila is a philosofishe grondslag (philosophical foundation), meaning the basis, ideology, outlook on life, philosophy, and goals of the Indonesian state (Siswoyo 2013). This is stated in the 4th paragraph of the opening (preambule) of the 1945 Constitution of the Republic of Indonesia which reads;

“... then the Indonesian National Independence was formulated in an Indonesian State Constitution, 
which was formed in a state structure of the sovereign Republic of Indonesia based on the belief in one Supreme God, just and civilized humanity, nationalism expressed in the unity of Indonesia, consultative democracy; and social justice for all Indonesian people."

In addition, the statement "Pancasila as the basis of the Indonesian state" is contained in the Decree of the House of Representative No. XVIII / MPR /1998, Article 1, which reads "Pancasila as referred to in the Preambule of the 1945 Constitution is the state foundation of the Unitary State of the Republic of Indonesia which must be carried out consistently in the life of the state."

As explained previously, the authentic Pancasila formulation is contained in the Preambule of the 1945 Constitution. Therefore, the adoption of the Pancasila as the basis of the Indonesian state coincided with the ratification of the 1945 Constitution as the constitution of the Republic of Indonesia, on August 18, 1945, a day after the proclamation of Indonesian independence. Pancasila is formulated into five principles (in the 1945 Constitution), namely;

1. Ketuhanan Yang Maha Esa (Belief in one Supreme God)

2. Kemanusiaan yang adil dan beradab (Just and civilized humanity)

3. Persatuan Indonesia (Indonesian Unity)

4. Kerakyatan yang dipimpin oleh hikmat kebijaksanaan dalam permusyawaratan dan perwakilan (Consultative Democracy led by the wisdom of deliberation and representation)

5. Keadilan sosial bagi seluruh rakyat Indonesia (Social justice for all Indonesian people).

The 1945 Indonesian Constitution is the highest legal rule of the State of Indonesia, and is referred to as a basic law. This is stated in Article 3 paragraph 1 of Law No. 12 of 2011 concerning the Establishment of Legislation which reads "The 1945 Constitution of the Republic of Indonesia is a basic law in the Legislation". It implies that all legal regulations must be in line and may not conflict with the 1945 Constitution. The 1945 Constitution consists of two parts, namely the opening (Preambule) and the Body of the Constitution. The body of the 1945 Constitution consists of 16 chapters and 37 articles, and the article governing education is Article 31 paragraphs 1 to 4 . Article 31, Paragraphs 1-4 of the 1945 Consitution of the Republic of Indonesia is formulated as follows:

1. Every citizen has the right to education.

2. Every citizen is obliged to have basic education and the government is obliged to finance it.

3. The government provides and organizes a national education system, which enhances the citizens' faithful, pious, and noble characters in order to educate the nation's life, as regulated by laws.

4. The state prioritizes the education budget of at least $20 \%$ of the State Budget and from the Regional Budget to meet the needs of national education.

The government promotes science and technology by upholding religious values and national unity for the advancement of civilization and the welfare of mankind.

\section{Discussion}

4.1. The sources of Values of the Indonesian Educational Philosophy

The philosophy and practice of the Indonesian education cannot be separated from the existence of Indonesia as a country. Indonesia has a state philosophy (philosophische grondslag) or state basic norms (staat fundamental norm) (Kailan 2013) or what Antonio Destutt de Tracy called Ideology (Jost et al. 2009). The basis of the state is the foundation on which a country stands. All countries in the world have their own State Foundation based on values that are believed to be true by their people. Ideology has a vital role in the life of the nation and state because ideology is an inspirational basis in all life activities (Jost et al. 2009; Dijk 1998).

As a sovereign country, Indonesia has a state foundation (staat fundamental norm), formulated by the founding fathers of the Indonesian state, namely Pancasila. Pancasila is not only an ideology of the state, but also the foundation of all sectors of national and state life (Wisudo et al. 2012). The ideology of Pancasila is not the result of the thoughts of individual founders of the Indonesian state, but the crystallization of the noble values of the Indonesian nation which are believed to be true, alive, and lived in everyday life (Kailan, 2013). Pancasila as the name implies; "Panca" means "five" and "sila" means "foundation", consisting of five principles arranged systematically, hierarchically, and logically. The five principles of the State of Indonesia constitute the universal values of the Indonesian multiculturalism that Soekarno called "Pancasila" (Notonegoro 1984; Ministry of Information of Indonesia 1980). Pancasila as the foundation of the state means that all sectors of life of the Indonesian nation and state, including Indonesian national education, must be based on and guided by Pancasila values (Siswoyo 2013). Pancasila is a belief system that becomes the mindset, attitude, and conviction of the Indonesian people (Djahiri \& Wahab 1996). So, logically and ideologically, Pancasila is the first and foremost source of values for the philosophy and practice of Indonesian education. This source is called the "philosophical or ideological foundation" of education.

Besides Pancasila, the basis of Indonesian education is the 1945 Constitution. An elaboration of Pancasila and the 1945 Constitution as the basis of Indonesian education is contained in Article 2 of Law No. 20 of 2003 concerning the National Education System. It states "National education is based on Pancasila and the 1945 
Constitution of the Republic of Indonesia". From the formulation, it is known that Pancasila and the 1945 Constitution are formally declared as the basis of Indonesian education in different functions. Pancasila serves the function as a "philosophical or ideological basis" while the 1945 Constitution is an "instrumental basis". Hierarchically, the 1945 Constitution is the highest order in Indonesian legislation Therefore, the 1945 Constitution is referred to as "basic law" (Law No. 12 of 2011). It means that all the laws that are under it, such as; the decrees of the the House of Representative, Law/Regulation in lieu of Law, Government Regulation, Presidential Decree, Provincial Regulation, and Regency/Municipal Regulations must not conflict with the 1945 Constitution. The Indonesian national education in stitulated in Article 31 Paragraphs 3 and 5 of the 1945 Constitution. Both sources, Pancasila and the 1945 Constitution, became the primary source of philosophical and practical values of the Indonesian education.

In addition to the two sources above, other sources that form the basis of Indonesia's national education are Laws, Government Regulations, Ministerial Regulations and Provincial, Regency/Municipal Regulations. These sources of value are called "practical bases" of Indonesian national education. So, in the Indonesian context, there are three educational foundations, namely philosophical, instrumental, and practical. These three fundations are built on the Indonesian culture, instead of on theoretical grounds constructed by individuals (Siswoyo 2013; Kaelan 2013). This means that the highest source of value in the Indonesian education system is Indonesia's multiculturalism. Therefore, if there is a conflict between the "practical basis" of education and the values of Indonesian culture, the cultural values of the Indonesian nation, i.e. multiculturalism, must be used to overcome the conflict.

\subsection{Indonesian Educational Philosophy}

In the Indonesian constitutional system, there are two main sources of values and norms; namely Pancasila and the 1945 Constitution. The position of Pancasila is higher than the 1945 Constitution, because Pancasila serves as the basis of the Indonesian State (Philosophische grondslag) formally contained in the Preambule of the 1945 Constitution. In contrast, the 1945 Constitution is the highest legal norm in the Indonesian legal system. Therefore, the 1945 Constitution is referred to as the basic law (Kailan 2013). It implies that the substance or content of the 1945 Constitution is a translation (instrumentation) of Pancasila, and therefore, the 1945 Constitution must not conflict with Pancasila.

Pancasila has five basic values contained in five principles that are holistic-integral, systematic, and hierarchical (Siswoyo 2013). Holistic-integral means that all principles of Pancasila are a unified and inseparable whole. Sistematic means the principles of Pancasila are one whole value that is arranged logically and correctly. Hierarchical means that the order of principles cannot be reversed in writing and interpretation (Kaelan 2016). The order of the principles of Pancasila is final. Therefore, to understand Pancasila values properly and correctly, one must study them thoroughly, sequentially, and interconnectedly. The five principles of Pancasila outlined in Article 31 of the 1945 Constitution becomes a philosophical source of Indonesian education. There are two categories of universal values contained in the Pancasila principles and Article 31 of the 1945 Constitution. They are religious and humanitarian values. Based on the categorization, it can be concluded that the philosophy of Indonesian education is "Religious Humanist Multiculturalism".

The value of "religious" is explicitly contained in the first principle of Pancasila, "the belief in one Supreme God" and the 1945 Constitution Article 31 paragraphs 3 and 5. The value of "religious" contained in the first principle of Pancasila and article 31 paragraphs 3 and 5 of the 1945 Constitution is the value based on the values lived by the Indonesian society in their religious practices of the religions and creeds acknowldeged by the State. There are 6 official religions professed by the Indonesian people, namely Islam, Catholicism, Protestantism, Hinduism, Buddhism and Confucianism. The five religions have the same theological base, namely "God Almighty". The One Supreme God is the most important value in the philosophy of life, as well as being the characteristics of the Indonesian people (Siswoyo 2013; Sumardi, 2012).

Theoretically, the Indonesian state administration regards the first principle of Pancasila as the "prima causa". First, the first principle is the cause of the second to fifth principles. So, the first principle becomes the source of value from the following principles. Hierarchically, it the value of the second principle comes from the first principle; the third principle comes from the first and second principles; the fourth principle comes from the first, second, and third principles, and the fifth principle from the first, second, third, and fourth. Second, God is the cause of existence or the creator of man and the universe (Kailan 2013, p. 58). Therefore, the Indonesian people must obey and submit to God Almighty. The submission of the Indonesian people towards the Almighty God can manifest in two forms, namely religion or creed (The 1945 Constitution Article 29 paragraph 2).

In the context of Indonesian education, the same principle applies, namely the first principle, the belief in one Supreme God (Religious) must be the basic value that embodies the Indonesian education both philosophically and practically. In addition, the values of religiosity must also be the first goal that must be achieved by students in learning, followed by other goals. So, the first function of Indonesian educational institutions is to teach students to have knowledge, attitudes, and religious morality. Lickona (2012) calls it moral knowing, moral feeling, and 
moral action. Thus, the role of Indonesian education is to nurture and develop students to have attitudes (affective), knowledge (cognitive), skills and morality (psychomotor). These three domains according to Piaget and Kohlberg must be owned by every student to be a good individual (Slavin 2000; Kohlberg 1995). The concept of Supreme God as contained in the first principle of Pancasila is the concept of the Multicultural God which is reflected in the religions adopted by every Indonesian citizen. To understand God and His teachings, every believer must learn their own religion through education.

The "humanist" value is explicitly and implicitly contained in the four principles of Pancasila, namely in the second to fifth principles, and in Article 31 paragraphs 3 and 5 of the 1945 Constitution. The four principles of Pancasila contain human values with variations in their respective values. The second principle, "Just and civilized Humanity", contains universal values, namely humanity. The second principle teaches that all humans, especially the Indonesian people must be treated according to the nature and objective conditions of man himself. Humans must be seen as beings who have the highest level compared to other creatures. In addition, humans must be seen in two elements of creation, namely physical and spiritual (Dewantara 2013, p. 47), because humans are created by God with these two elements. Human spiritual elements according to Berger (Muhadjir 2013, p. 20-24) have open instincts that develop according to their socio-cultural conditions. Therefore, everyone must treat other humans humanely, in accordance with their nature and socio-cultural values. The treatment is not only related to their physical aspects, but also includes their spiritual aspects. That is what is meant by being "fair and civilized" in the second principle of Pancasila. It implies that every Indonesian must receive just and civil treatment according their existence as God creature and cultural being, without being discriminated against their race, ethnicity, religion and culture.

The third principle of Pancasila contains the value of unity. This unity value will be realized if universal human values are already shared among the Indonesian people. So, the requirement to apply the value of unity is the internalization of the value of humanity in every soul of the Indonesian people. Without the value of humanity, unity cannot be realized. Therefore, the third principle of Pancasila teaches the Indonesian people that all Indonesians are the same and united. This is in accordance with the Indonesian slogan "Bhineka Tunggal Ika" which means "unity in diversity" (Dewantara 2013, p. 184; Kailan 2016, p. 72). Unity does not mean eliminating differences and empirically different characteristics of the nation. However, meaningful unity has the same inner bonds and sense of humanity as Indonesian people. National unity will occur if every person, group, and faction accepts and respects differences.

The fourth principle of Pancasila contains the value of democracy. Democracy refers to a democracy based on insight and wisdom. Democracy is related to freedom and equality (Feu et al. 2017). Most importantly, democracy, according to Lincoln (Surbakti 1998, p. 62), is the involvement of all elements or society in all aspects of life. In the fourth principle, everything related to the common interest must be discussed and must involve community participation. Deliberation according to the principle must be done wisely and prudently. It must be wise and reasonable. In addition, deliberation must uphold the values of morality, courtesy, and culture (Dewantara 2013, p. 46). In the deliberation, the most important thing is togetherness and cooperation among all components. For the interaction and cooperation to happen among the people, they must have an equal position. There is no superordinate and subordinate position because everyone has the same position (Muhadjir 2003, p. 63).

The fifth principle of Pancasila contains the value of justice. According to the fifth principle, every Indonesian person must be treated equally in all aspects of life. There should be no discriminating treatment based on cultural, religious, racial and ethnic differences. All people must be seen as one big family, namely the Indonesian family, and treated the same as their own family. In addition, justice means that everyone must be given the same opportunity to participate in all aspects of life, without coercion and intimidation.

Article 31 paragraphs 3 and 5 of the 1945 Constitution contains the values of national unity, harmony and integrity. In building togetherness, national unity and integrity according to the paragraph must be based on a noble character based on multicultural religious teachings. The humanitarian philosophy referred to in Pancasila and the 1945 Constitution is the same as the humanitarian concept proposed by Pestalozzy (Heafford 1967), Dewey (Gutek 1974), and Freire (Smith 2008), namely education or learning must be done democratically, without curbing others, and in accordance with the conditions or development of the child.

The educational philosophy based on the Indonesian values is not limited to Religious-Humanist, but the Religious-humanist philosophy is based on the culture of multiculturalism. This is based on the real condition of the Indonesian nation which is multi-religious and multicultural, and is one of the pillars of the life of the Indonesian nation and state. It is clear that Indonesia's philosophy of education is the Multicultural Religious Humanism. It means that the Indonesian people are religious human beings who are multicultural as reflected in "Bhineka Tunggal Ika" or Unity in Diversity. The value of the Religious Humanism combines two sources of strength of value, namely values derived from God that are transcendent (transcendental ethics) and values that are built on the basis of individual interactions in society (non-transcendental ethics) (Muhadjir 2013). Education that is built on the basis of religious philosophy has advantages compared to education that is built on the basis of other philosophies (Brubacher 1978). The merging of two sources of philosophical values which gave birth to the 
Religious-humanist philosophy will have a better impact on education than the philosophy which is only based on one value.

\subsection{Implication on Education}

The Religious Humanist Multiculturalism philosophy is an educational philosophy that is built on the basis of the diverse values of the Indonesian people. "Eclectic incorporating" actions towards the philosophy and practice of education carried out so far could be the reason why Indonesian education continues to lag behind other countries, because the existing education philosophy is not suitable with the characteristics and culture of the Indonesian people. The Religious Humanist Multiculturalism philosophy has several implications for education. First, religious education is a compulsory subject that must be taught at all levels of education, unlike in most Western countries where education is secular, the curriculum does not contain religious education (Brubacher 1978, p. 148). Religious education given to students is suitable with the religion adopted by each student, so that they become obedient to God and have a noble character in accordance with their religious teachings.

Second, the philosophy of the Religious Humanist Multiculturalism does not require the application of a uniform curriculum. The applied curriculum must be adapted to the conditions, characteristics, and culture of each multicultural region. The application of a uniform curriculum can create problems in student learning, because the manners and results of student learning are greatly influenced by their experiences in their cultural environment. Therefore, the applied curriculum must be relevant to students (Townsend 2007, p. 1947-1948; Hurn 1998, p. $127-$ 132).

Third, on the aspects of learning practice, the Religious Humanist Multiculturalism philosophy requires schools to create communal spaces, cooperation, tolerance, and mutual respect for differences. The philosophy of Religious Humanist also requires a democratic, open, and interactive learning atmosphere, without any pressure and intimidation. Students learn happily and fun. Schools should not be a frightening place for students (Heafford 1967, p. 40). On the contrary, schools should become a pleasant and happy living space. Schools must be able to carry out their functions, namely to make humans become real human beings (Stolz 2018). In addition, learning must be done impartially, in which teachers must treat all students equally. There should be no discrimination against students based on ethnicity, race, religion, and students' abilities, because such actions have a negative impact on students (Townsend 2007, p. 157-159). The teacher's learning must be customized with the learning culture of each student in each cultural society.

\section{Conclusion}

Indonesia has an educational philosophy that is derived from the country's philosophy, Pancasila. Pancasila is stated in the state constitution, the 1945 Constitution, and is further elaborated in more detail in other laws. The philosophy of Indonesian education is different from the philosophy of secular-humanism Western education. The philosophy of Indonesian education as stipulated in Pancasila and emphasized in the 1945 Constitution is the philosophy of the Religious Humanist Multiculturalism. It refers to the philosophy based on religious values and humanity originating from Indonesia's multiculturalism. Likewise, in the practice of education, curriculum development and learning practices in the classroom cannot be done with a student-centered humanism approach. Learning that is inspired by the Indonesian philosophy of education and culture is a balance between the role of teacher and students in learning (student-teacher-centered). The teacher must take the role of a leader in learning by providing the biggest possible space for students to be creative.

\section{References}

Affifi, R. et al. (2017). Introduction to ecologizing philosophy of education. Studies in Philosophy and Education, 36(3), 229-241. https://doi.org/10.1007/s11217-017-9574-3.

Indonesian National Planning Agency. (2018). "2018 Indonesia's population reaches 265 million people". Retrevied from https://databoks.katadata.co.id/.

Biesta, G. and Peters, M. (2015). Alternative futures and future alternatives for the philosophy of education: Introduction to the symposium. Studies in Philosophy and Education, 34(6), 619-621. https://doi.org/10.1007/s11217-015-9492-1.

Biesta, G. \& Peters, M. (2015). Editorial: Positive news about the feature of philosophy of education. Studies in Philosophy and Education, 34(1), 1-3. https://doi.org/10.1007/s11217-014-9456-x.

Bleicher. (2013). Contemporary hermeneutics; Hermeneutics as a method, philosophy, and criticism. Yogyakarta: Fajar Pustaka.

Central Bureau of Statistics of Indonesia. (2018). "Indonesian statistic 2018." Retrevied from https://www.bps.go.id/.

Brubacher. (1978). Modern Philosophis of education. USA: McGraw-Hill.

Constitution of The Republik of Indonesia 1945. Secretary General of the Indonesian House of Representative.

Determination of the Indonesian House of Representative No. XVIII/MPR/1998 about Revocation of 
Determination of Indonesian House of Representative No. II/MPR/1978 about Guidelines for Living and Practicing Pancasila (Ekaprasetia Pancakarsa) and Determination of the Affirmation of Pancasila as the Foundation of the State.

Dewantara. (2013). Ki Hajar Dewantara; Thought, conception, exemplary, attitude of independence. Book I; Education. Yogyakarta: UST Press.

Djahiri and Wahab. (1996). Basis and concept of moral education. Jakarta: Depdikbud.

Enslin and Horsthemke. (2006). "Philosophy of education: Becoming less western, more Africa?" Journal of Phylosophy of Education, 50(2), 178-190. https://doi.org/10.1111/1467-9752.12199

Feu, J. et al. (2017). Democracy and education: A theoritical proposal for the analysis of democratic practice in school. Studies in Philosophy and Education, 36, 1-15. https://doi.org/10.1007/s1 1217-017-9570-7.

Gobet. (2017). Three views on expertise: Philosophica implication for rationality, knowledge, intuition, and education. Journal of Philosophy of Education, 52(1), 605-619. https://doi.org/10.1111/1467-9752.12253.

Gutek. (1974). Philosophical alternatives in education. Ohio: Charles E. Merrill Publishing Company.

Heafford. (1967). Pestalozzi. Methuen \& Co Ltd.

Hurn. (1998). The limits and possibilities of schooling; An introduction to the sociologi of education. USA: Allyn and Bacon, Inc.

Jost, Nosek, and Gosling. (2009). Ideology its resurgence in social, personality, and political psychology. Perspectives on Psichological Science, 3(2), 126-136. https://doi.org/10.1111/j.1745-6916.2008.00070.x.

Kaelan. (2016). Pancasila philosophy. Yogyakarta: UGM Press.

Ministry of Education and Culture of Indonesia. (2014). "Concept of curriculum 2013". Paper Presented at Natiolal Conference on Education, Makasar, April 29.

Law of the Republic of Indonesia No. 20 of 2003 concerning the National Education System. Minister of Education and Culture of Indonesia.

Law of the Republic of Indonesia No. 12 of 2011 concerning Establishment of Legislation. Republic of Indonesia Ministry of Law and Human Rights.

Masyhud. (2018). "Education management in strengthening character education in primary schools". Paper Presented at National Conference of Education, April 11.

Muhadjir. (2013). Re-interpretive phenomenological education. Yogyakarta: Rake Sarasin.

Mulyono. (2013). Learning hermeneutics; From the philosophical configuration to the praxis of islamic studies. Jogjakarta: IRCiSoD.

Notonegoro. (1984). The birth of the Pancasila. Ministry of Information of the Republic of Indonesia.

Santo and Eremers. 1995. Stages of Moral Development. Yogyakarta: Kanesius.

Siswoyo. (2013). Bung Karno's view on Pancasila and education. Cakrawala Pendidikan, 32(1), 103-115. https://doi.org/10.21831/cp.v5i1.1264.

Slavin. (2000). Educational psychology theory and practice. USA: By Allyn \& Bacon.

Smith. (1987). The meaning of conscientizacao; The goal of Paulo Freire's pedagogi. Massachusetts: University of Massachusetts Amherst.

Soeharto. (2010). Educational idiology debate. Cakrawala Pendidikan, 29(2): https://doi.org/10.21831/cp.v2i2.334

Stolz. (2018). Geneological analysis of the concept of "Good" teaching: A polemic. Journal of Philosophy of Education, 52(1), 144-162. https://doi.org/10.1111/1467-9752.12270.

Sumardi, L. (2012). The revitalization of social sciences teaching in elementary school as an effort to create students who have good character. SOCIA: Jurnal Ilmu-Ilmu Sosial, 11(2), 157-164. https://doi.org/10.21831/socia.v11i02.36.02.

Sumardi, L., Rispawati, \& Ismail, M. (2017). The effect of information technology on learning (A study on Civic and Pancasila Education students at Mataram University). Jurnal Pendidikan dan Pembelajaran, 24(2), 7378.

Sumardi, L. (2014). Telaah rencana program pembelajaran Pendidikan Pancasila dan Kewarganegaraan sekolah dasar di Kota Mataram [Anlysis of the planning program of civic education for elementary education in Mataram city]. EL-HIKAM, VII(2), 309-324.

Suparlan. (2015). Educational philosophy of Ki Hadjar Dewantara and his contribution to Indonesian education. Jurnal Filsafat, 25(1), 56-74. https://doi.org/10.22146/jf.12614.

Surbakti. (1998). Introduction to politics. Rajawali Press.

The International Commission of Financing Global Education Opportuniti (2016). The learning generation; investing in education for a changing world. A Report by the International Commission of Financing Global Education Opportuniti.

Townsend. (2007). "School effectiveness and improvement in the twenty-first century: Reframing for the future". In T Townsend: International Handbook of School Effectiveness and Improvement, 933-962. Netherland: Springer. 
Wahyudin. (2018). "Mathematics learning and strengthening character education". Paper Presented at National Conference of Education, April 11.

Wahyudiati, D., Rohaeti, E., Irwanto, Wiyarsi, A., \& Sumardi, L. (2020). Attitudes toward chemistry, self-efficacy, and learning experiences of pre-service chemistry teachers: Grade level and gender differences. International Journal of Instruction, 13(1), 235-254. https://doi.org/10.29333/iji.2020.13116a.

Wangid. (2009). Among systems in the present: Conceptual study and practice of education. Jurnal Kependidikan, 39(2), 129-140. https://doi.org/10.21831/jk.v39i2.

Wikepedia. (2018). "Natural resources". Retrevied from https://id.wikipedia.org/wiki/Sumber_daya_alam.

Wisudo et al. (2012). Pancasila that is educating. Jakarta: Sekolah Tanpa Batas.

ZHAO. (2013). Rebuilding the Chinese soul: Some considerations for education. Frontiers of Education in China, 8(4), 498-517. https://doi.org/10.3868/s110-002-013-0034-7. 